\title{
How the Student's Error in Solution of Mathematics Problems?
}

\author{
Dwi Erna Novianti \\ Fakultas Pendidikan Matematika dan IPA, IKIP PGRI Bojonegoro. \\ Jalan Panglima Polim No 46, Bojonegoro 62114, Indonesia. \\ E-mail: Dwi.Erna@ikippgribojonegoro.ac.id
}

Article received : April 2019, article revised : June 2019, article published: September 2019

DOI : 10.25273/jipm.v8i1.4163

\begin{abstract}
This qualitative descriptive study aimed to analyze student errors to solve mathematical problems in gender. The subject in this research were Mathematics Education students in the Linear Program subject. The sample selection used purposive sampling by looking at the results of student tests on linear program material categorized by gender. The analysis data using observation methods, test methods and interview methods, meanwhile to validity test of the data using triangulation of data source and triangulation method. Based on the results of the study obtained results: 1) Errors experienced by male and female students are almost similar, but the mistakes experienced by female students are fewer than male students, 2) Female and male students with high ability categories possess different types of errors, namely female students only experience process errors and results of errors, while male experience transformation errors, process errors, results in errors, 3) Female and male students with low ability categories have the same type of errors, namely misunderstanding, transformation errors, process errors, results errors. In this study also none of the subjects experienced reading errors.
\end{abstract}

Keywords: Student Error Analysis; Mathematical Problem-Solving; Gender.

\section{INTRODUCTION}

Mathematics is the basis of all science; therefore, mathematics has been introduced early on, starting from education kindergarten to the tertiary level. Learning mathematics is an ongoing process to obtain new concepts, ideas, and knowledge-based on previous experience so that it can help us to think critically, logically, accurately, effectively and efficiently (Lipianto \& Budiarto, 2013). The achievement of the objectives of mathematics learning, one of it can be measured from the success of students in understanding mathematics and utilizing this understanding to solve problems.

There are reasons why problem-solving in mathematics is important. As stated by Sujarwo (Erna, Umi, \& Ari, 2017) which states that mathematical problem solving is important to do, including problem-solving will develop cognitive skills, can foster creativity, and is part of the application process of mathematics and part of student motivation in learning mathematics. The importance of solving the problem was also raised by Liljedahl, Santos-Trigo, Malaspina, \& Bruder (2016) stated that mathematical problem solving has long been seen as an important aspect of mathematics, the teac hing of mathematics, and the learning of mathematics. It has infused mathematics curricula around the world with calls for the teaching of problemsolving as well as the teaching of mathematics through problem-solving (Liljedahl et al., 2016).

The ability to solve mathematical problems is one of the abilities students must have to see the relevance of mathematics to other subjects, as well as in real life. Students are said to be able 
to solve mathematical problems if they can understand, choose the right strategy, then apply it in problem-solving. Good mathematical problem-solving skills also affect results learn mathematics to become better (Siagian, 2016). This is consistent with the opinion (Cahyani \& Setyawati, 2016) in his research, which states that the ability of problemsolving has a positive influence on learning outcomes in mathematics. If this problemsolving ability continues to develop, student learning outcomes will also develop. However, mathematical problem solving is still a difficulty for students (Phonapichat, Wongwanich, \& Sujiva, 2014; Tambychik \& Meerah, 2010).

Solving these mathematical problems requires several steps for completion. Completion includes from the initial stage to the end, namely from the stage of understanding the problem to the stage of finding a solution. The stage of understanding the question is an important stage because, at this stage, students are required to understand the purpose and objectives of the problem (Mahmudah, 2015). Problem-solving skills are strongly related to students ability to read and understand the language of story problems, present in mathematical models, plan calculations from mathematical models, and complete calculations of non-routine problems (Jha, 2012). Story questions can be made by modifying questions that were originally in the form of counts and then related to daily life or reality in the students' environment. Meanwhile, Cahyani, in her research on the error in working on story problems in mathematics learning, said that story problems were still quite difficult for some students (Cahyani \& Setyawati, 2016).

Based on the results of tests on linear programming conducted on mathematics students in semester VI in solving story problems, the results are still low. The test results show that students cannot understand the meaning of the questions, have not been able to translate the questions into mathematical sentences, and are not accurate in calculating. Most students find it difficult to solve these mathematical problems, resulting in errors in finding a solution. Previous research on difficulties in solving linear programming problems was also carried out by Mustaqin who stated that difficulties occur in understanding problems then transferring in the form of variables as well as errors in compiling tables, so it does not reflect that the table serves to facilitate writing the objective function (Mustaqim, 2013).

The mistakes made by these students need to be analyzed to find out the types of mistakes made and why they were made. The mistakes made by these students can be used as consideration for teaching in an effort to improve learning and teaching activities. An increase in learning and teaching activities is expected to improve learning outcomes. In this study, the analysis conducted is different from the existing research because it analyzes students mistakes based on gender so that the result obtained can describe the mistakes between male and female students.

To analyze the error, one of the procedures that can be used is Newman or procedure, Newman's Error Analysis (NEA). NEA is designed as a simple diagnostic procedure in solving mathematical story problems. Meanwhile Newman Siswandi \& Sujadi (2016) states there are five errors found is reading problems (reading), understand the problems (comprehension), the transformation of matter (transformation), process skills (process-skill) and encoding/ inferences (encoding). Some mistakes made are certainly influenced by many factors. For example, the incompatibility 
of methods and learning processes provided by the teacher can also cause students to experience errors in working on math problems. According to Siswandi \& Sujadi (2016), a common mistake made by students is a lack of understanding of symbols, place values, calculations, incorrect use of processes, and unreadable writing.

On the other hand, there are many factors that need to be considered in learning mathe-matics, including the will, ability, certain intelligence. Factors that are no less important are gender or gender. Gender has an important role because the patterns of thinking between men and women are certainly different, and this also influences how to solve mathematical problems. Some supporting theories about gender are the first, according to Zubaidah Amir, which states that gender differences not only result in differences in abilities in mathematics but also ways to obtain mathematical knowledge (Căprioară, 2015; Geary, Saults, Liu, \& Hoard, 2000; Raduan, 2010). The second supporting theory is that the gender factor in mathematics is due to biological differences in the brains of boys and girls which are known through observation, that girls, in general, are superior in language and writing, while boys are superior in mathematics because of its better spatial ability. Women generally focus on things that are concrete, practical, emotional, and personal, while men are focused on things that are intellectual, abstract, and objective (Geary et al., 2000).

Meanwhile, the ability of boys is slightly better than that of women in mathematics and science, thus allowing male students to be better than female students in mathematics, because mathematics is generally concerned with understanding abstract (Amir, 2013). This difference in problem-solving abilities based on gender can also be an indicator of the different difficulties experienced by male and female students. This is consistent with previous research conducted by Asizah Wardani, which states that male students are unable to carry out plans and check back, while female students are able to carry out plans and check back even though it is incomplete (Wardani, 2014). The results of other studies indicate that gender differences and resilience affect the achievement of abilities, which can also be interpreted that the success of students in mathematics is influenced by gender factors (Rohaeti, 2010). The novelty in this study is there are described the students error in Linear Program material.

Based on the description, the problems regarding the types of students' mistakes based on gender in solving mathematical problems in the form of interesting story problems for researchers, so that researchers examine further about the types of errors experienced by students based on gender in solving mathematical problems in linear program subjects.

\section{METHODS}

This research was conducted on students taking Linear Program courses. This research is descriptive qualitative research because it describes the types of mistakes made by students in understanding story problems. Descriptive study in which there is an attempt to describe, record, analyze, and interpret the conditions that currently occur. The error analyzed is a type of error based on Newman, namely reading errors, understanding problems, problem transformation, process skills and coding/drawing conclusions in solving story problems (essays) in a linear program course. 
Qualitative research does not use population, because qualitative research departs from certain cases that exist in certain social situations and the results of the study will not be applied to the population but transferred to other places on social situations that have similarities with social situations in the cases studied. The sampling technique in this study uses a non-probability with sampling technique purposive sampling. In this study, the total number of students who took the problemsolving test was 47 students. Of these eight students were taken as research subjects. The criteria for selecting research subjects are based on gender (male and female) who have high and low problem-solving abilities based on predetermined value criteria in solving story problems in linear program subjects.

Data collection techniques are the most important step in research because the main purpose of the research is to collect data. Data collection methods in this study used the method of observation, test methods, interview methods, and documentation methods. In the observation activities, the researchers conducted a direct learning process, and observation data will be presented in the form of a narrative free description. This data is used to strengthen data on the causes of student errors in solving mathematical problems in the form of problem-solving. This test method is a test designed for the purpose of diagnosing mistakes made by students in solving mathematical problems in the form of solving linear programming problems. The interview was conducted to explore the location of student mistakes in solving problems. This interview activity is also used to gather information about the factors that cause these errors. The documen-tation method in this study was carried out to record or perpetuate activities in the form of photographs and grades, and student work.

The instruments in this research are interview guidelines and problem-solving tests. Before being used for research, all of these instruments are validated beforehand by the validator. Therefore, test instruments in the form of essays in this study will still be tested, namely, the validity test in the form of content validity. The type of essay questions used consists of 4 questions with criteria in the form of story questions that are really related to linear program problems, and the questions given can measure students' problem-solving abilities. Content validity is the validity of which focus on the elements of what was in the measure (Wong, Law, \& Wong, 2002). Test content is a representative sample of the entire contents of the thing to be measured. Validity test is done by reviewing or reviewing test items by the validator. A test is a rational approach, which is to compare the problem with the problem grille. So, the high or low validity of the contents depends on the suitability between the test items with the grid.

The data analyzed in this study are data reduction, data presentation, and conclusion drawing or verification. The data reduction stage in this study includes: (1) Correcting student work results by scoring, (2) Grouping data based on gender, (3) Conducting interviews with several research subjects, and the results of these interviews are simplified to form a good and neat language. Presentation of data is done by giving initials so that readers are clearer and easier to understand. In this study, the subjects were given their initials namely: KTL1 for subjects with High Male Capabilities (1), KTL2 for subjects with High Male Capabilities (2), KTP1 for subjects with High Female Capabilities (1) 
and KTP2 for Subjects with High Women's Ability (2). Other initials are KRL1 for lowability male subjects (1), KRL2 for low-male ability subjects (2), KRP2 for low-ability female subjects (2) and KRP2 for low-ability female subjects (2) The presentation of the interview transcript is done by making a conversation code to make it easier for readers to understand the brief description that has been made. Conclusion Withdrawal or verification by comparing the results of student work and the results of the interview can be drawn from the conclusion of the location and answer errors.

In this study, checking the validity of the data using the method triangulation. Triangulation used in this research is method triangulation, which is done by comparing data obtained from interviews with test results. (2) Triangulation of methods, namely by using more than one research strategy to obtain the same information. For this reason, two methods are used, namely checking the level of confidence in the discovery of the results of several techniques used in data collection and checking several data sources using the same method. The triangulation view of the method is intended to vary and validate the qualitative analysis. The process of triangulation of methods in this study is as follows:

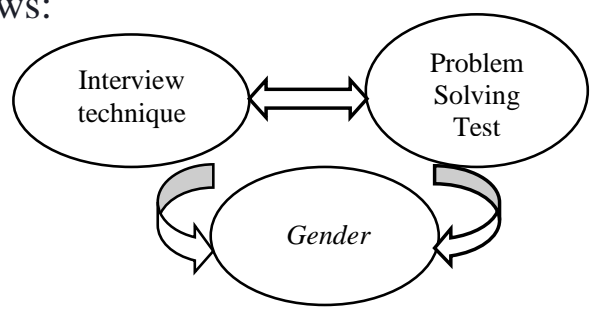

Figure 1. Triangulasi Method

\section{RESULT AND DISCUSSION}

The process of solving mathematical problems requires several steps of completion, starting from the initial step of understanding the problem, planning a solution and doing a solution. The following are examples of exposure to test results and interview results for students with low ability criteria, namely by one of the Low Ability Women 1 informants (KRP 1)

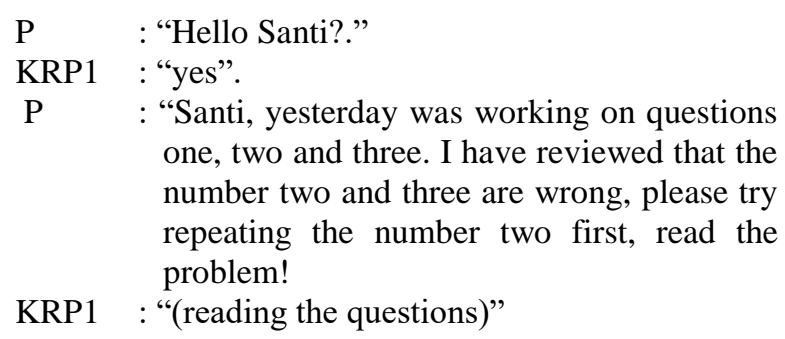
one, two and three. I have reviewed that the number two and three are wrong, please try repeating the number two first, read the problem!

KRP1 :"(reading the questions)"

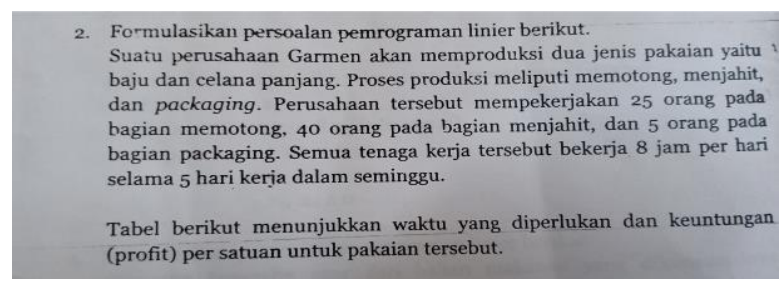

Figure 2. Problem-solving question

This interview was conducted with informal talks, but the statements submitted were in accordance with the guidelines that had been made. This is done to facilitate communication, so that what researchers want can be obtained to the maximum, here are the answer scripts from KRP1.

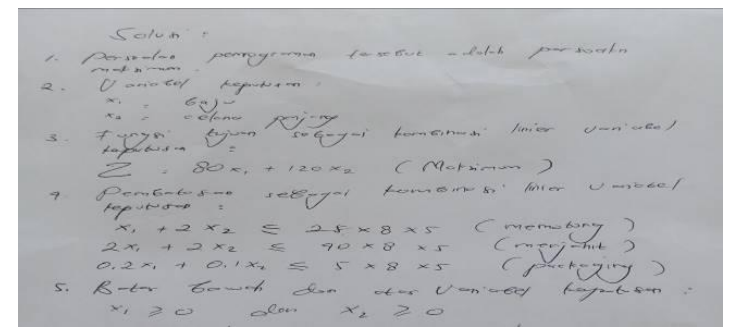

Figure 3. KRP1 solution

P : "out of the question, you understand the point?"

BKP1 : "yes"

P : : "Now let's see you answer"

BKP1 : "(look at the answers)" 
P : : try to look at the function of limiting the third"

BKP1 : "Yes Mom, something's wrong with the third delimiter function."

Based on the interview excerpt, it appears that at the stage of understanding the problem is not good, because it does not understand the problems presented, so it can not continue the process of finding solutions to solving the problem. Based on the results of the study conducted, the following is a Table 1 . of the overall results of the subject for the criteria of errors made by students with low ability.

Table 1. Criteria for the Error of Students with Low Ability

\begin{tabular}{|c|c|c|c|c|c|c|}
\hline NO & Criteria & $\begin{array}{c}\text { Reading } \\
\text { error }\end{array}$ & $\begin{array}{c}\text { Comprehen } \\
\text { sion error }\end{array}$ & $\begin{array}{c}\text { Transformatio } \\
\text { n error }\end{array}$ & Process error & Result error \\
\hline 1 & KRP1 & - & $\sqrt{ }$ & $\sqrt{ }$ & $\sqrt{ }$ & $\sqrt{ }$ \\
\hline 2 & KRP2 & - & $\sqrt{ }$ & $\sqrt{ }$ & $\sqrt{ }$ & $\sqrt{ }$ \\
\hline 3 & KRL1 & - & $\sqrt{ }$ & $\sqrt{ }$ & $\sqrt{ }$ & $\sqrt{ }$ \\
\hline 4 & KRL2 & - & $\sqrt{ }$ & $\sqrt{ }$ & $\sqrt{ }$ & $\sqrt{ }$ \\
\hline
\end{tabular}

As for students with high abilities, the following are examples of exposure to test results and interview results for students with high ability criteria, namely by one of the male High Ability 1 informants (KTL1).

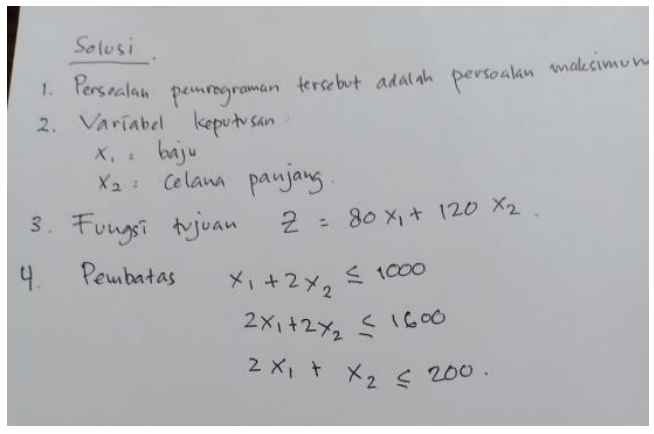

Figure 4. KTL1 solution

Q : : For number 2, try to see the answer!"

KTL1 : "Yes ma'am."

Q : :Is the answer correct like this?"

KTL1 : "Yes I am right look for the objective function and barrier function."

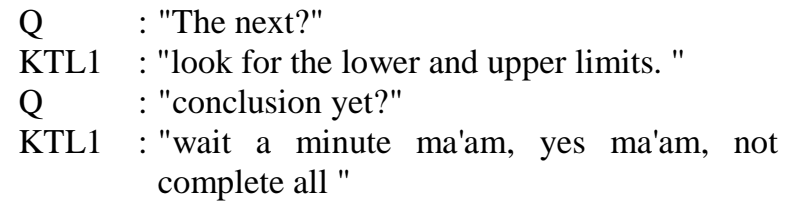

The interview was conducted formally so that the researcher obtained the results of valid information from reading the KTL1 requestions realize that there is one more step that hasn't been worked on. In the interview excerpt KTL1 can rework and actually understand what is meant by the problem, but it is still wrong to transform what is understood so that it results in process errors and result errors. Based on the results of the research conducted, the following is a table of the overall results of the informants for the criteria of errors made by students with high ability.

Table 2. Criteria for the Error of Students with High Ability

\begin{tabular}{ccccccc}
\hline No & Criteria & $\begin{array}{c}\text { Reading } \\
\text { error }\end{array}$ & $\begin{array}{c}\text { Comprehension } \\
\text { error }\end{array}$ & $\begin{array}{c}\text { Transformation } \\
\text { error }\end{array}$ & $\begin{array}{c}\text { Process } \\
\text { error }\end{array}$ & $\begin{array}{c}\text { Result } \\
\text { error }\end{array}$ \\
\hline 1 & KTP1 & - & - & - & $\sqrt{ }$ & $\sqrt{ }$ \\
2 & KTP2 & - & - & - & $\sqrt{ }$ & $\sqrt{ }$ \\
3 & KTL1 & - & - & $\sqrt{ }$ & $\sqrt{ }$ & $\sqrt{ }$ \\
4 & KTL2 & - & - & $\sqrt{ }$ & $\sqrt{ }$ & $\sqrt{ }$ \\
\hline
\end{tabular}

Based on the results in Table 2., student errors in solving problems are very different between male students and female students. This research examines students' mistakes in 
solving problems based on gender. Based on the type of error Newman (Jha, 2012), the results of this study have classified the types of errors experienced by students in the KTP (High Ability Female) category and students in the KTL (High Ability Male) category. There are differences in errors that occur between female subjects and male subjects. The difference in errors that occur between the two, namely, the female subject experienced a process error and result error while the male subject with high ability experienced transformation errors, process errors, and error results.

These differences reveal that the error rate experienced by the KTP is less than the KTL. This is as expressed by (Adhadika \& Pujiyono, 2014) that in certain circumstances women's productivity is higher than men, for example in terms of accuracy and patience. These results indicate that in working out or solving women's problem solving problems more thoroughly and patiently so that the types of mistakes experienced by women are less than men.

Research conducted by Nuryoto explains that there is evidence that women have better levels of learning achievement than men, women are more motivated and study more diligently than men in school work. Better learning achievement in women is of course because they are better at understanding the lessons they receive than men. Male students are not diligent in learning, have difficulty concentrating or are responsible, even boys cannot divide their time between playing with learning. Female students are more able to divide their time between playing and learning because of their obsession with the achievements of their two masters and almost all of the winners are women (Nuryoto, 1998).
Based on the opinions expressed by several experts, in this study KTL is less thorough or careless in solving mathematical problems, so there is a transformation error in the process resulting in process errors and results errors, this means there are different types of errors between KTP students and KTL students. These results, indicate that there are different types of errors experienced by subjects with low ability, in which the subject experiences an error type of understanding, transforming, processing, and results. While subjects with high ability to make a few types of errors experienced are transformation errors, processes, and results. However, students with high and low ability have the same type of error, namely process and outcome errors.

The difference in the types of errors there are certainly underlying factors include different learning abilities between them. Learning ability is interpreted as evidence of success achieved from the activities that have been done. Learning ability is achievement is the result achieved by students through a learning achievement test, which aims to find out the picture of student absorption, to determine the level of student achievement on a subject (Phonapichat et al., 2014; Singh, Rahman, \& Hoon, 2010). From this opinion it can be seen that there are differences in results between subjects with low ability and with high ability, ie the results of the subject's value of high ability are better than low ability, so that the type of error experienced is also less.

Types of errors according to Newman Jha (2012) are reading errors, misunderstanding, transformation errors, result errors, process errors, and result errors. In this study all subjects were examined using the Newman error indicator. From the whole subject, there 
are some who experience a type of error, namely error understanding, transformation, process, results. From the results of the study also obtained that all subjects experienced no reading errors.

The discussion of the mistakes made by each subject is as follows:

1. Data on the results of tests and interviews of two subjects between KRP1 and KRP2 show they both experienced the same type of error, namely understanding errors, transformation errors, process errors, and error results. Based on this, from two representative subjects namely KRP1 and KRP2, it can be concluded that overall students with low ability categories of women in this study experienced errors of understanding, transformation, process, and results.

2. Data of two subjects between KRL1 and KRL2 representing KRL subjects in this study, there are similarities in errors between the two, namely errors in understanding, transformation, process, and results. Based on this, it can be concluded that the exposure of data that has been found shows that the two subjects that represent the low ability of men are valid. So it can be concluded that male students with low ability categories experience errors of understanding, transforming, process, and results. Male and female subjects with low abilities experience the same mistakes.

3. Data of two subjects between KTP1 and KTP2 both show the same type of error. Based on the data of the KTP findings as a whole is able to work on problem solving problems, but from the procedure of solving both subjects the KTP experienced a process error, ie they have not been able to solve the problem properly so both of them experienced a process error and resulted in an error result. From exposure to the findings data, it can be concluded that the female high ability category students in this study experienced process and outcome errors.

4. Data on two KTLsubjects 1 and KTL2, which represented the high ability of men in this study, experienced the same error, namely from both the subject of transformation error, process error, and result error. Based on the explanation of these findings, in this study it can be said that male students with high abilities category experienced transformation errors, process errors, and error results.

Based on the discussion of each subject, the errors experienced by all subjects in solving the problem are the results and process errors. Errors experienced by low ability students begin with misunderstanding of the problem, the error of the transformation of the problem and result in errors in the process and the results of the settlement.

Students with low ability both men and women, experience errors of understanding, transformation, results and processes in solving mathematical problems. This is in line with the results of research Masfingatin, Murtafiah, \& Krisdiana (2017) that students with low ability in solving the problem of proving geometry theorems have not been able to understand theorems, have not been able to make connections between definitions, postulates and theorems so they have not been able to arrange logical proofs. This shows that students have not been able to transform theorems and related concepts so that the process of proof and the results of proof are not logical. In the end the student did not arrive at proof.

Errors experienced by male students with high abilities include errors of transformation, which affect the process and results. The ability of transformation becomes the 
most important ability, which influences the process and outcome of problem solving. This opinion is in line with Tambychik \& Meerah (2010) that a good mathematical ability without being equipped with the ability to transfer information and transform problems will not be able to understand and make effective relationships of information in the problem. The result is an error both in the process and the results of problem solving. Reading errors are not experienced by all students. This is because students already have the ability to read good questions. Another thing is a question given in a language that is understood by students (not a foreign language). These results are in line with research conducted by (Amalia, 2017) which states that the type of error that occurs in students occurs in understanding errors, processes and results errors. The same results were also obtained by Junaedi in his research which stated that errors that occur in students when working on geometry problems also occur at the stage of the process (process) and transformation stage (transformation), and do not experience reading errors (Junaedi, 2012).

However, some research also shows a reading error (Raduan, 2010; Sai \& Rejeki, 2017; Singh et al., 2010). The results of research conducted by Sa'i showed that there were $74 \%$ reading errors experienced by students, they states that students experience language difficulties $32 \%$ and the remaining $68 \%$ experience difficulties relating to contentknowledge when confronted with math problems in English. Raduan stated that students' reading errors in problem solving in the form of story problems were the smallest percentage of errors $(0.34 \%)$ and errors in understanding the problems that were the most errors experienced by students (52.91\%).

Based on several studies that have been mentioned there are similarities and differences with the results of this study. This difference is certainly influenced by some of the most important factors are the types of problems faced by students, differences in initial abilities, material and level of mastery of students. It is also influenced by students' experience in problem solving (Căprioară, 2015). The more often students are faced with problems in the form of problems the more experienced the problem solving process. Student experience in problem solving can minimize mistakes made.

\section{CONCLUSION}

The conclusion of the results of this study is that there are various types of errors according to Newman experienced by students with low ability, which include errors of understanding, transformation, process and results. Errors experienced by male students with high abilities include errors of transformation, processes and results while female students with high abilities only experience process and outcome errors. Students do not experience reading errors in the process of solving mathematical problems.

Based on the research findings, the researcher recommends further research in order to explore deeper about the causes of differences in errors experienced by male and female students with high ability in problem solving and the factors causing them. 


\section{REFERENCES}

Adhadika, T., \& Pujiyono, A. (2014). Analisis Faktor-Faktor Yang Mempengaruhi Produktivitas Tenaga Kerja Industri Pengolahan di Kota Semarang. Accounting Analysis Journal, 3(3), 1-13. https://doi. org/ISSN 2252-6765

Amalia, S. R. (2017). Analisis Kesalahan Berdasarkan Prosedur Newman Dalam Menyelesaikan Soal Cerita Ditinjau Dari Gaya Kognitif Mahasiswa. Aksioma, 8(1), 17. https://doi.org/10.268 77/aks.v8i1.1505

Amir, Z. (2013). Perspektif Gender Dalam Pembelajaran Matematika. Marwah: Jurnal Perempuan, Agama Dan Jender, 12(1), 15. https://doi.org/10.24014/mar wah.v12i1.511

Cahyani, H., \& Setyawati, R. W. (2016). Pentingnya Peningkatan Kemampuan Pemecahan Masalah melalui PBL untuk Mempersiapkan Generasi Unggul Menghadapi MEA. PRISMA, Prosiding Seminar Nasional Matematika, 151-160.

Căprioară, D. (2015). Problem Solving - Purpose and Means of Learning Mathematics in School. Procedia - Social and Behavioral Sciences, 191, 1859-1864. https://doi. org/10.1016/j.sbspro.2015.04.332

Erna, N. D., Umi, K. A., \& Ari, I. (2017). The Math Problem Solving Profile in Solve Linear Programming ' sProblem Based On Mathematic Communication Ability. JIPM (Jurnal Ilmiah Pendidikan Matematika), 6(1), 53-59. Retrieved from http://journal.unipma.ac.id/index. php/jipm JIPM

Geary, D. C., Saults, S. J., Liu, F., \& Hoard, M. K. (2000). Sex Differences in Spatial Cognition , Computational Fluency , and Arithmetical Reasoning. Journal of Experimental Child Psychology, 77,
337-353. https://doi.org/10.1006/jecp. 2000.2594

Jha, S. K. (2012). Mathematics performance of primary school students in Assam (India): An analysis using Newman Procedure. International Journal of Computer Applications in in Engineering Sciences, II(I), 17-21. Retrieved from http://search.ebscohost.com/login.aspx? direct $=$ true $\&$ profile $=$ ehost $\&$ scope $=$ site $\&$ authtype $=$ crawler $\&$ jrnl $=22314946 \& A N$ $=82881779 \& \mathrm{~h}=\mathrm{EVVQDh} / \mathrm{Hm} 52 \mathrm{chAMl}$ wrzR4w4wi7jATMnDU2PdIoLeamUS/ cc4YNQKyx+qkOW4Z0IJs51nz6+2xG bl75NrT1SSwg==\&crl=c

Junaedi, I. (2012). Tipe Kesalahan Mahasiswa dalam Menyelesaikan Soal-Soal Geometri Analitik Berdasar Newman's Error Analysis (NEA). Kreano Jurnal Matematika Kreatif-Inovatif, 3(2), 125133. https://doi.org/10.15294/kreano. v3i2.2872

Liljedahl, P., Santos-Trigo, M., Malaspina, U., \& Bruder, R. (2016). Problem Solving in Mathematics Education. https://doi.org/10.1007/978-3-31940730-2_1

Lipianto, D., \& Budiarto, M. T. (2013). Analisis kesalahan siswa dalam menyelesakan soal yang berhubungan dengan persegi dan persegipanjang berdasarkan taksonomi solo plus pada kelas vii. Mathedunesa, 2(1). Retrieved from http://jurnalmahasiswa.unesa.ac.id/ index.php/mathedunesa/article/view/1218

Mahmudah, S. (2015). Peningkatan Keterampilan Menyelesaikan Soal Cerita Matematika Menggunakan Media Kartu Kerja Pada Siswa Kelas II SDN Purworejo Kecamatan Kandat Kabupaten Kediri. Jurnal PINUS, 1(2), 165-173. 
Masfingatin, T., Murtafiah, W., \& Krisdiana, I. (2017). Kemampuan mahasiswa calon guru matematika dalam pemecahan masalah pembuktian teorema geometri. Jurnal Mercumatika: Jurnal Penelitian Matematika Dan Pendidikan Matematika, 2(2), 41-50.

Mustaqim. (2013). Berdasarkan Diagnosis Kesulitan Siswa dalam Menyelesaikan Masalah Program Linear dengan Menggunakan. Pendidikan MatematikaUniversitas Negeri Malang, 1, 72-78.

Nuryoto, S. (1998). Perbedaan Prestasi Akademik Antara. Jurnal Psikologi, (2), 16-24. Retrieved from https://media. neliti.com/media/publications/127308ID-perbedaan-prestasi-akademik-antaralaki.pdf

Phonapichat, P., Wongwanich, S., \& Sujiva, S. (2014). An Analysis of Elementary School Students' Difficulties in Mathematical Problem Solving. Procedia Social and Behavioral Sciences, 116, 3169-3174. https://doi.org/10.1016/j. sbspro.2014.01.728

Raduan, I. H. (2010). Error analysis and the corresponding cognitive activities committed by year five primary students in solving mathematical word problems. Procedia - Social and Behavioral Sciences, 2(2), 3836-3838. https://doi. org/10.1016/j.sbspro.2010.03.600

Rohaeti, E. E. (2010). Critical and Creative Mathematical Thinking of Junior High School Students. Educationist, IV(2), 99-106.

Sai, M., \& Rejeki, S. (2017). Analisis Kesalahan Mahasiswa dalam Menyelesaikan Soal Cerita pada Materi Probabilitas di Program Studi Pendidikan Teknik Informatika. KONTINU: Jurnal
Penelitian Didaktik Matematika, 1(1), 38-46.

Siagian, M. D. (2016). Kemampuan Koneksi Matematika Dalam Pembelajaran Matematika. MES (Journal of Mathematics Education and Science), 2(1), 58-67.

Singh, P., Rahman, A. A., \& Hoon, T. S. (2010). The Newman procedure for analyzing Primary Four pupils errors on written mathematical tasks: A Malaysian perspective. Procedia - Social and Behavioral Sciences, 8(5), 264-271. https://doi.org/10.1016/j.sbspro.2010.12 .036

Siswandi, E., \& Sujadi, I. (2016). Analisis Kesalahan Siswa Damam Menyelesaikan Masalah Kontekstual Ditinjau dari Perbedaan Gender ( Studi Kasus pada Siswa Kelas VII SMPN 20 Surakarta ). Jurnal Elektronik Pembelajaran Matematika, 4(7), 633-643.

Tambychik, T., \& Meerah, T. S. M. (2010). Students' difficulties in mathematics problem-solving: What do they say? Procedia - Social and Behavioral Sciences, 8(5), 142-151. https://doi.org/ 10.1016/j.sbspro.2010.12.020

Wardani, A. K. (2014). Kemampuan Pemecahan Masalah Berdasarkan Perbedaan Jenis Kelamin ( Ability of Problem Solving From Diferences of Sex ). Jurnal Pendidikan Matematika STKIP PGRI Sidoarjo, 2(1), 99-108.

Wong, C., Law, K. S., \& Wong, P. (2002). Development and validation of a nonself-report emotional intelligence measure in Hong Kong. Asian Academy of Management Conference, 535-559. https://doi.org/10.1023/B:APJM.000004 8717.31261.d0 